\title{
Electrochemical Corrosion Behavior of X52 and X60 Steels in Carbon Dioxide Containing Saltwater Solution
}

\author{
Rihan Omar Rihan* \\ Center for Engineering Research, Research Institute King Fahd University of Petroleum \& Minerals - KFUPM, \\ Dhahran 31261, Saudi Arabia
}

Received: May 16, 2012; Revised: September 13, 2012

\begin{abstract}
X52 and X60 high strength low alloy (HSLA) steels are widely used in the construction of petroleum pipelines. This paper discusses the corrosion resistance of X52 and X60 steels in $\mathrm{CO}_{2}$ containing saltwater at $\mathrm{pH} 4.4$ and $50{ }^{\circ} \mathrm{C}$. A circulating flow loop system inside an autoclave was used for conducting the experimental work. The rotating impeller speed was $2000 \mathrm{rpm}$. The corrosion rate was monitored using in situ electrochemical methods such as potentiodynamic sweep, linear polarization resistance, and electrochemical impedance spectroscopy (EIS) methods. Results indicated that the corrosion rate of X60 steel is relatively higher than that of X52 steel.
\end{abstract}

Keywords: $\mathrm{CO}_{2}$ corrosion, petroleum pipelines, high strength low alloy (HSLA) steel, X52 steel, X60 steel

\section{Introduction}

Carbon dioxide $\left(\mathrm{CO}_{2}\right)$ gas is one of the most common gases which occurs with the crude oil. The dissolution of $\mathrm{CO}_{2}$ gas in water forms corrosive environments which attack the carbon steel pipe walls ${ }^{1}$. $\mathrm{CO}_{2}$ gas occurs naturally in oil and gas reservoirs and dissolves in water to form carbonic acid $\left(\mathrm{H}_{2} \mathrm{CO}_{3}\right)$.

The processes, which simultaneously take place in $\mathrm{CO}_{2}$ corrosion of mild steel are $^{2}$ :

Chemical reactions. $\mathrm{CO}_{2}$ is sparingly soluble in water (Reaction 1) and produces $\mathrm{H}_{2} \mathrm{CO}_{3}$, which is a weak acid (Reaction 2):

$C O_{2(g)} \Leftrightarrow \mathrm{CO}_{2(w)}$

$\mathrm{CO}_{2(w)}+\mathrm{H}_{2} \mathrm{O} \Leftrightarrow \mathrm{H}_{2} \mathrm{CO}_{3}$

$\mathrm{H}_{2} \mathrm{CO}_{3}$ partially dissociates in two steps to form bicarbonate $\left(\mathrm{HCO}_{3}^{-}\right)$ions (Reaction 3 ) and carbonate $\left(\mathrm{CO}_{3}^{2-}\right)$ ions (Reaction 4):

$\mathrm{H}_{2} \mathrm{CO}_{3} \Leftrightarrow \mathrm{H}^{+}+\mathrm{HCO}_{3}$

$\mathrm{HCO}_{3}^{-} \Leftrightarrow \mathrm{H}^{+}+\mathrm{CO}_{3}^{2-}$

The process of homogenous Reactions 3 and 4 occur at much faster rates than the other simultaneously occurring processes in the system. The processes of Reaction 1 and particularly Reaction 2 have been known to occur as much

*e-mail: rihan@kfupm.edu.sa slower processes (rate controlling), and may lead to local non-equilibrium in the system.

The formation of solid iron carbonate $\left(\mathrm{FeCO}_{3(\mathrm{~s})}\right)$ (Reaction 5) is an important chemical reaction usually observed in aqueous $\mathrm{CO}_{2}$ solutions:

$$
\mathrm{Fe}^{+}+\mathrm{CO}_{3}^{2-} \Leftrightarrow \mathrm{FeCO}_{3(s)}
$$

The precipitation of $\mathrm{FeCO}_{3(\mathrm{~s})}$ (predominantly on the surface of the steel) will occur only once the concentrations of local $\mathrm{Fe}^{2+}$ and $\mathrm{CO}_{3}{ }^{2-}$ exceed the solubility limit of $\mathrm{FeCO}_{3(\mathrm{~s})}$. The formation of $\mathrm{FeCO}_{3(\mathrm{~s})}$ usually plays an important role in the process of corrosion since the $\mathrm{FeCO}_{3(\mathrm{~s})}$ layer increases the mass transfer resistance of the corrosive species and reduces the exposed steel surface area to the corrosive environment. In fact, in many cases, the presence of the $\mathrm{FeCO}_{3(\mathrm{~s})}$ layer largely controls the $\mathrm{CO}_{2}$ corrosion rate.

Electrochemical reactions. There are a number of electrochemical reactions that take place in $\mathrm{CO}_{2}$ corrosion process. The reduction of $\mathrm{H}^{+}$(Reaction 6) is considered one of the key cathodic processes.

$$
2 \mathrm{H}^{+}+2 e \rightarrow \mathrm{H}_{2}
$$

Reaction 6 is usually limited by how fast the $\mathrm{H}^{+}$can be transported from the bulk solution to the steel surface through the mass transfer boundary layer and the $\mathrm{FeCO}_{3(\mathrm{~s})}$ layer (if it exist).

The adsorption of $\mathrm{H}_{2} \mathrm{CO}_{3}$ at the steels surface (Reaction 7) is followed by the reduction of $\mathrm{H}^{+}$, which is referred to as "direct reduction of carbonic acid". Reaction 7 is, in essence, an alternative pathway of Reaction 6 . 
$2 \mathrm{H}_{2} \mathrm{CO}_{3}+2 e \rightarrow \mathrm{H}_{2}+2 \mathrm{HCO}_{3}$

The direct reduction of water is another possible pathway for hydrogen evolution (Reaction 8). Reaction 8 is very slow compared to the above cathodic reactions and commonly is neglected in estimating effects of practical $\mathrm{CO}_{2}$ corrosion environments.

$2 \mathrm{H}_{2} \mathrm{O}+2 e \rightarrow \mathrm{H}_{2}+2 \mathrm{OH}^{-}$

For the anodic reaction, there is often only one dominant anodic reaction (at the corrosion potential) is involved in the $\mathrm{CO}_{2}$ corrosion process. Iron oxidation is the anodic reaction of mild steel in $\mathrm{CO}_{2}$ corrosion process (Reaction 9).

$\mathrm{Fe} \rightarrow \mathrm{Fe}^{2+}+2 e^{-}$

Transport. Concentration gradients are built up between steel surface and bulk solution as a result of the consumption and evolution of certain species at the steel surface, which leads to molecular diffusion. The rates of the overall reaction by transport will be limited compared to some fast electrochemical reactions such as Reaction 6 since mass transfer of $\mathrm{H}^{+}$proceeds much slower.

Oxygen can contribute to the corrosion process by oxygen reduction reaction (Reaction 10) and by hydrogen evolution from direct reduction of water (Reaction 11), although it is not considered a common corrosive specie in oil and gas pipeline systems ${ }^{3}$.

$\mathrm{O}_{2}+2 \mathrm{H}_{2} \mathrm{O}+4 e \rightarrow 4 \mathrm{OH}^{-}$

$2 \mathrm{H}_{2} \mathrm{O}+2 e \rightarrow \mathrm{H}_{2}+2 \mathrm{OH}^{-}$

Reaction 10 is comparatively very slow, always possible, and is important only at $\mathrm{CO}_{2}$ partial pressure $<<0.1$ bar and $\mathrm{pH}>6^{4,5}$.

Experimental research conducted by Han et al. ${ }^{6}$ indicates that the formation of $\mathrm{FeCO}_{3}$ layer only failed to passivate the surface. The surface passivated after the formation of magnetite phase $\left(\mathrm{Fe}_{3} \mathrm{O}_{4}\right)$.

The loss in the metal mass caused by general corrosion is generally proportional to temperature and $\mathrm{CO}_{2}$ partial pressure $^{7}$. Nevertheless, it is well documented that a precipitation layer on the steel surface is promoted at certain conditions, i.e. elevated temperature and $\mathrm{pH}>6$. This layer is reported to be iron carbonate $\left(\mathrm{FeCO}_{3}\right)^{8}$ and it has a mitigating effect on $\mathrm{CO}_{2}$ corrosion 9 .

Modelling has been performed by a number of researchers ${ }^{2,3,10-12}$. The state-of-the-art in modelling of internal corrosion of oil and gas carbon steel pipelines was reviewed by $\mathrm{Nesic}^{13}$.

The $\mathrm{CO}_{2}$ corrosion in petroleum facilities is a serious concern since it is difficult to predict, understand and control. The failure of in-service components as a result of erosion-corrosion and $\mathrm{CO}_{2}$ corrosion has long been responsible for major safety concerns, lost production time, and cost in the maintenance of the steel materials used in petroleum industries.
Approximately $60 \%$ of the failures in oilfields are related to $\mathrm{CO}_{2}$ corrosion. This $\mathrm{CO}_{2}$ failure is mainly related to low corrosion resistance of carbon steels and to lack of prediction $^{14}$. $\mathrm{CO}_{2}$ corrosion has been reported as the major cause of failures in some oilfields ${ }^{15}$.

In latest years, the mechanical properties of plain carbon steels have been greatly improved by micro alloying the plain carbon steels with small amounts (max 0.1 wt. (\%)) of strong carbide and nitride forming elements such as $\mathrm{Nb}$, Ti and V. The produced steels are known as High Strength Low Alloy (HSLA) steels ${ }^{16}$.

HSLA steels are widely used in oil and gas production and transportation pipelines. HSLA steels have a low price-to-yield strength ratio. The weldability of HSLA steels is considered good due to their low carbon contents. The minimum yield strength value is used to designate the API grade HSLA steels. For example, the designed yield strength of API-X60 steel is $60 \mathrm{ksi}(414 \mathrm{MPa})^{16}$.

There are numerous standard test methods developed for testing and studying the corrosion resistance of metals/alloys. Studying the effect of flow on corrosion has been commonly performed by different testing methods, such as rotating cylinder electrodes ${ }^{17,18} /$ disk $^{19-21}$ electrodes, impinging-jet test rigs ${ }^{21-24}$, rotating cages $^{25}$, stationary electrodes $^{26-28}$, and flow loops ${ }^{29-36}$.

Data on electrochemical corrosion behavior of HSLA steels exposed to $\mathrm{CO}_{2}$ containing solutions are not widely reported or available. Moreover, the use of a flowing system inside an autoclave is not commonly investigated as part of the other testing methods mentioned above. Therefore, it is important to study the behavior of the HSLA steels in $\mathrm{CO}_{2}$ containing solution environment. The study presented below aims at filling in this gap. In addition to generating new knowledge on corrosion of HSLA steels in $\mathrm{CO}_{2}$ containing solution environment using flowing system inside an autoclave. The objective of this work was to compare the corrosion behavior of two HSLA steels (X52 and X60) that are commonly used in pipe fabricated for use in petroleum transport pipelines. The steels were exposed to $\mathrm{CO}_{2}$ containing saltwater solution in a circulating fluid system contained within an autoclave.

\section{Experimental Apparatus}

The apparatus used in this experimental work was a high-pressure/high-temperature autoclave. This autoclave is equipped with fluid circulating system as illustrated in Figure 1. The main components of the experiment setup are described below.

\subsection{Autoclave (heating pressure vessel)}

The autoclave is a 5.6 liter pressure vessel acting as a reservoir for the solution surrounded by an electric heater to heat the solution. The autoclave is made from 316 stainless steel internally clad with Hastelloy C276, which has an excellent erosion-corrosion resistance to hot acidic solution. It is equipped with a variable speed motor to rotate the impeller, a pocket to house a thermocouple for measuring the temperature of the solution inside the autoclave, and a $\mathrm{CO}_{2}$ gas connection. The design pressure is $20.7 \mathrm{MPa}$ at $260{ }^{\circ} \mathrm{C}$. 


\subsection{Electrochemical testing}

The experimental set up is equipped with the following electrodes in order to perform electrochemical measurements:

Working electrodes. There are two working electrodes inserted on the working electrode shaft as illustrated in
Figure 1. The working electrode is a circular ring inserted on the working electrodes shaft. The dimensions of the working electrode are $25 \mathrm{~mm}$ outside diameter, $15 \mathrm{~mm}$ inside diameter, and $7.5 \mathrm{~mm}$ height. The working electrodes are made from the material to be tested, which is X52 and X60 HSLA steels in this study. The working electrodes were machined from actual X52 and X60 HSLA pipes.

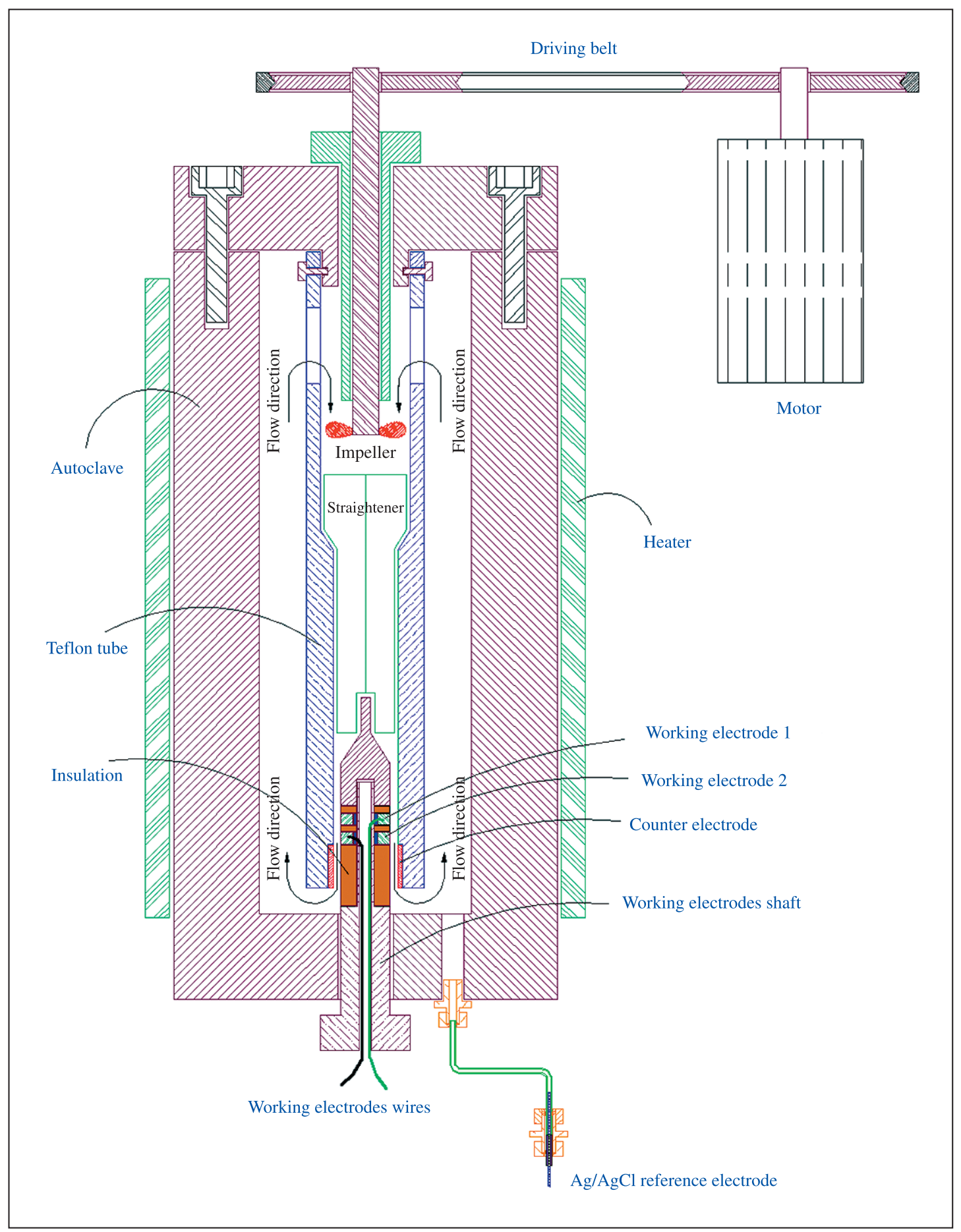

Figure 1. A cross section of the autoclave. 
Counter electrode. The counter electrode is a circular ring placed around the working electrodes as illustrated in Figure 1 in order to ensure a symmetrical current distribution during electrochemical polarization measurements. The counter electrode is made from Hastelloy C276.

Reference electrode. There is only one external $\mathrm{Ag} / \mathrm{AgCl}$ reference electrode attached to the autoclave. The reference electrode is a simple $\mathrm{Ag}$ rod coated by $\mathrm{AgCl}$ which was prepared by anodically polarizing the Ag rod in a saturated $\mathrm{KCl}$ solution at room temperature. A current density of $10 \mathrm{~mA} \cdot \mathrm{cm}^{-2}$ was used for three minutes in order to coat the rod with a durable $\mathrm{AgCl}$ layer. In the experiments the reference electrode was continuously wetted by the solution which was extracted from the autoclave and cooled to room temperature, by natural convection. The IR drop resulting from varying distance between the reference electrode and the two working electrodes was measured to be very small due to the high conductivity of the solution.

\subsection{Flow straightener}

The flow straightener is placed just before the working electrodes shaft as shown in Figure 1 in order to stabilize the flow. The flow straightener allows the flow to pass through four separate paths and recombine again before passing over the working electrodes shaft.

\section{Experimental}

The specimens were prepared by grinding with 600 grit paper, then washed by ethanol and allowed to dry. The electrolyte was made by dissolving 3 wt. (\%) $\mathrm{NaCl}$ in distilled water. The selected concentration of $\mathrm{NaCl}$ was chosen to simulate to the concentration in actual oil production process. The $\mathrm{NaCl}$ was analytical reagents grade.

The $\mathrm{NaCl}$ solution was placed in the autoclave and the solution was heated to $50{ }^{\circ} \mathrm{C}$ while running the motor at a speed of $2000 \mathrm{rpm}$ and de-aerating the solution with $\mathrm{CO}_{2}$ for about 3 hours till the $\mathrm{pH}$ reached 4.4 , then the following electrochemical measurements started. The impedance spectra were normalized to $1 \mathrm{~cm}^{2}$.

\section{Results and Discussion}

The corrosion rate was monitored using in situ electrochemical methods such potentiodynamic polarization, linear polarization resistance, and electrochemical impedance spectroscopy (EIS) methods.

\subsection{Potentiodynamic polarization measurements}

The potentiodynamic polarization curves of the X52 and X60 steels are illustrated in Figure 2. The scan range was -250 to $250 \mathrm{mV}$ vs. open circuit potential $\left(\mathrm{E}_{\mathrm{oc}}\right)$ and the scan rate was $0.167 \mathrm{mV} / \mathrm{s}$. The potentiodynamic polarization curves indicate that $\mathrm{E}_{\text {corr }}$ of X52 steel $(-437 \mathrm{mV})$ was relatively more positive than that of the $\mathrm{E}_{\text {corr }}$ of X60 steel $(-454 \mathrm{mV})$.

Figure 2 shows that cathodic curves of X53 and X60 steels showed little change, although the anodic curves were dependent on the steel grades. The anodic current density of X60 steel was slightly higher than that of X52 steel.

The values of anodic $\left(\beta_{\mathrm{a}}\right)$ and cathodic $\left(\beta_{\mathrm{c}}\right)$ Tafel slopes of the X52 and X60 steels were determined as illustrated in Table 1.

Table 1. Anodic $\left(\beta_{\mathrm{a}}\right)$ and cathodic $\left(\beta_{\mathrm{c}}\right)$ Tafel slopes of the X52 and X60 steels.

\begin{tabular}{ccc}
\hline Steel grade & $\beta_{\mathrm{a}}\left(\mathbf{m V . d e c a d e ^ { - 1 }}\right)$ & $\beta_{\mathrm{c}}\left(\mathbf{m V . d e c a d e}{ }^{-1}\right)$ \\
\hline X52 & 38 & 150 \\
X60 & 34 & 134 \\
\hline
\end{tabular}

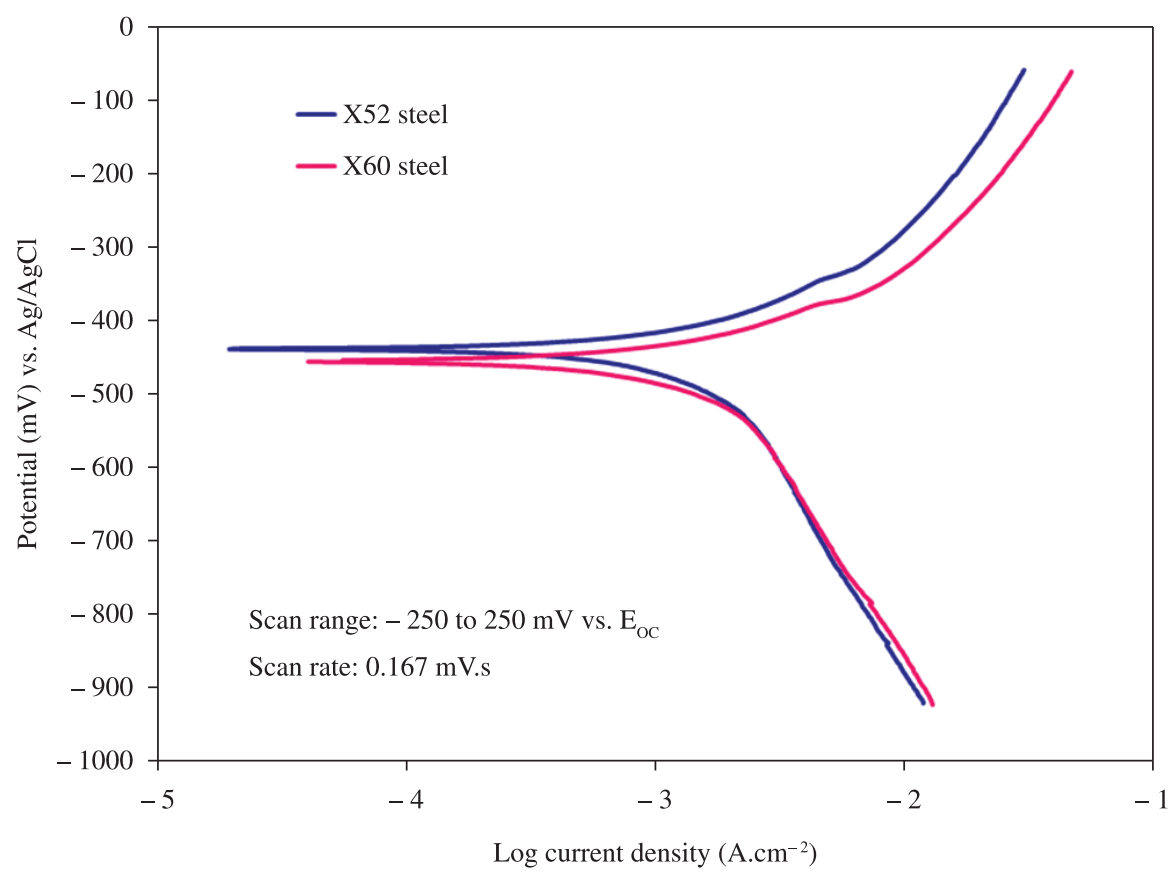

Figure 2. The potentiodynamic polarization curves of the X52 and X60 steels. 


\subsection{Polarization resistance measurements}

This method was used to obtain the polarization resistance $\left(R_{p}\right)$ from the slope of the potential/current curve. The measurements were done by polarizing the working electrode $6 \mathrm{mV}$ above and below the open circuit potential at scan rate of $0.1 \mathrm{mV} / \mathrm{s}$.

The corrosion current $\left(i_{\text {corr }}\right)$ was calculated by using Equations 1 and 2:

$$
i_{\text {corr }}=\frac{\mathrm{B}}{\mathrm{R}_{\mathrm{p}}}
$$

where:

$i_{\text {corr }}$ is the corrosion current density in A.m ${ }^{-2}$;

$\mathrm{R}_{\mathrm{p}}$ is the polarization resistance in $\Omega \cdot \mathrm{m}^{2}$ and

$\mathrm{B}$ is the proportionality constant in $\mathrm{V}_{\mathrm{dec}} \mathrm{deade}^{-1}$ :

$\mathrm{B}=\frac{\beta_{\mathrm{a}} \beta_{\mathrm{c}}}{2.3\left(\beta_{\mathrm{a}}+\beta_{\mathrm{c}}\right)}$

where:

$\beta_{\mathrm{a}}$ is anodic Tafel constant in V.decade ${ }^{-1}$ and

$\beta_{c}$ is cathodic Tafel constant in V.decade ${ }^{-1}$.

The corrosion rate $(C R)$ measured by the electrochemical method was calculated by using Equation (3):

$C R=\frac{i_{c o r r} w}{\rho F}$

where:

$w$ is the equivalent weight of $\mathrm{Fe}$,

$F$ is Faraday constant, and

$\rho$ is the density of Fe.
The corrosion rate of X60 steel was slightly higher than that of X52 steel (Figure 3). The corrosion potential $\left(\mathrm{E}_{\text {corr }}\right)$ of X60 is relatively more negative than that of X52 steel (Figure 4) which indicates that the corrosion rate of X60 steel is more than that of X52 steel which fully agreed with Figure 3. These results are consistent with data obtained from potentiondynamic polarization technique.

The standard deviation and confidence level (95.0\%) of the corrosion rate and corrosion potential were determined using Microsoft Excel as illustrated in Table 2.

In order to quantitatively evaluate the effect of the $\mathrm{CO}_{2}$ containing saltwater on the resistance of each of the two steel grades to erosion-corrosion, the total amount of metal lost during the whole experiment was determined for X52 and X60 steels, by integrating the areas under the corrosion rate curves shown in Figure 3. The results for the two steels are shown in Figure 5. It can be seen that the metal loss of X60 steel was higher than that of X52 steel.

\subsection{Electrochemical impedance spectroscopy (EIS) measurements}

EIS measurements are shown in Figures 6 (Nyquist) and 7 (Bode). The frequency range is $0.1-10^{6} \mathrm{~Hz}$. EIS results show a clear difference between the two materials, and are considered more useful than polarization techniques for comparison of the materials. The corrosion resistance was found, in comparison, to be $196 \Omega \mathrm{cm}^{2}$ (X52 steel) and $147 \Omega . \mathrm{cm}^{2}$ (X60 steel). The EIS measurements thus confirm the findings from potentiodynamic polarization and linear polarization resistance techniques.

Based on the previous findings, the corrosion rate of X60 steel grade is higher than that of X52 steel grade as measured by potentiodynamic polarization, linear

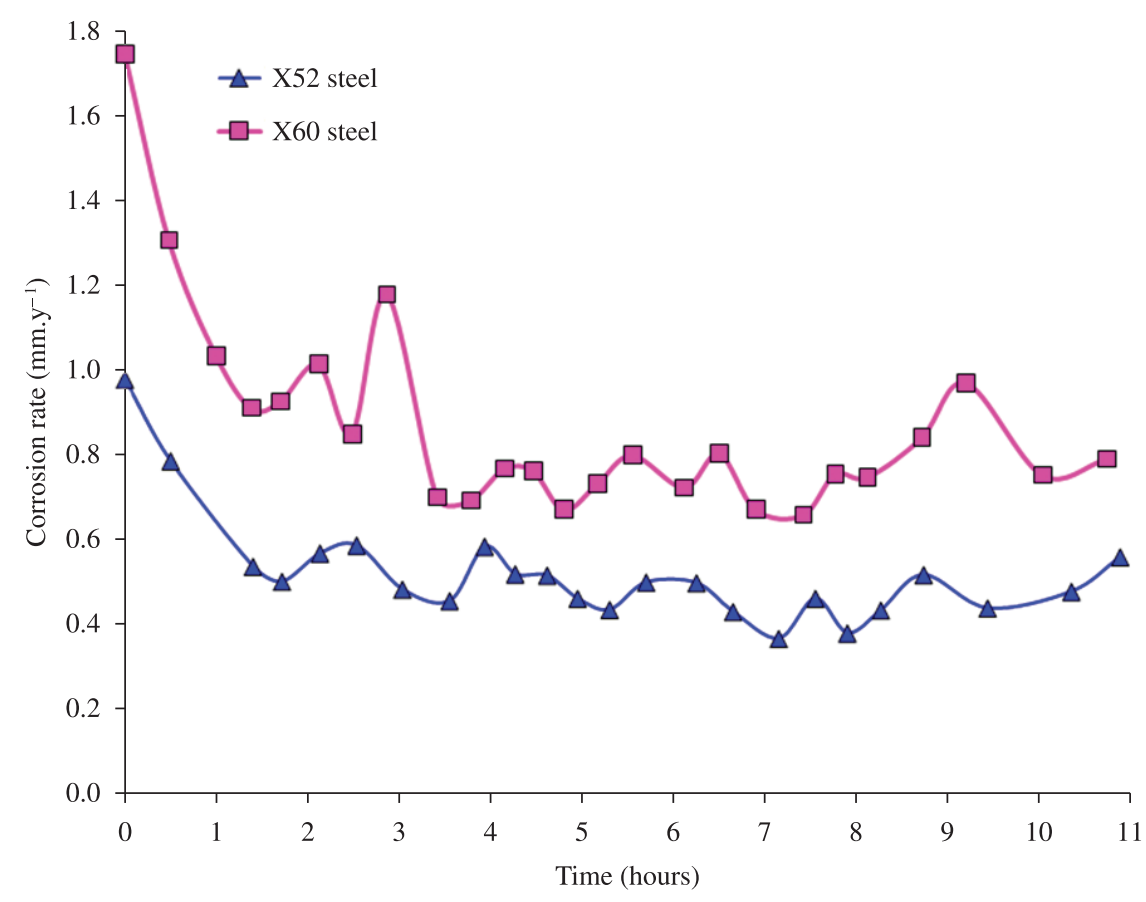

Figure 3. Corrosion rate versus time for X52 and X60 HSLA steels. 
Table 2. The standard deviation and confidence level (95.0\%).

\begin{tabular}{cccc}
\hline Steel grade & $\begin{array}{c}\text { Standard } \\
\text { deviation }\end{array}$ & $\begin{array}{c}\text { Confidence } \\
\text { level }(\mathbf{9 5 . 0 \%})\end{array}$ \\
\hline X52 & $\begin{array}{c}\text { Corrosion rate } \\
\text { Corrosion } \\
\text { potential }\end{array}$ & 0.129 & 0.054 \\
& 13.416 & 5.665 \\
$\mathrm{X} 60$ & $\begin{array}{c}\text { Corrosion rate } \\
\text { Corrosion } \\
\text { potential }\end{array}$ & 0.244 & 0.101 \\
\hline
\end{tabular}

polarization resistance, and electrochemical impedance spectroscopy methods.

The corrosion rates of both steel grades decreased significantly and the corrosion potential increased significantly during the first hour of immersion then stabilized with little fluctuation during the rest of the experiments. This significant decrease in corrosion rate and increase in corrosion potential might be attributed to the formation of a protective film.

There were no major differences in the final corrosion rates, measured at the end of the experiment, across the

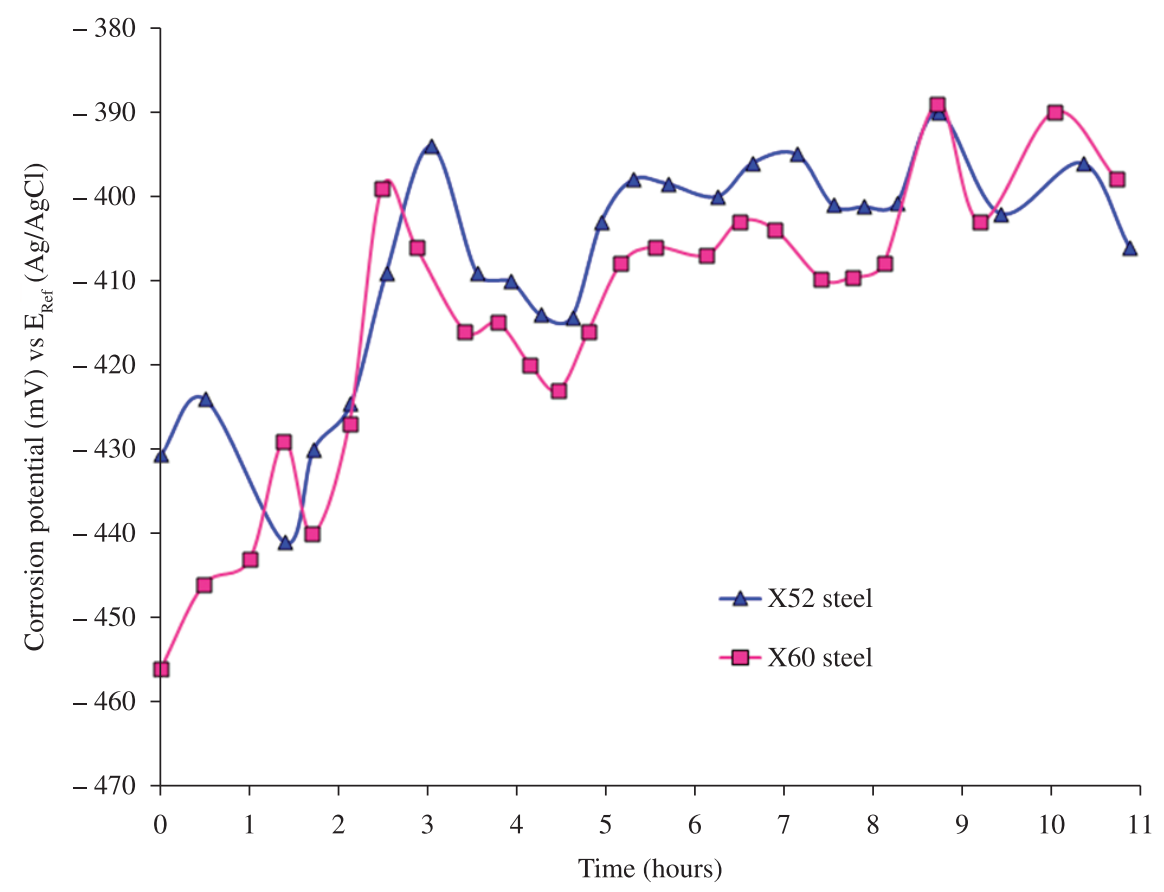

Figure 4. Corrosion potential versus time for X52 and X60 HSLA steels.

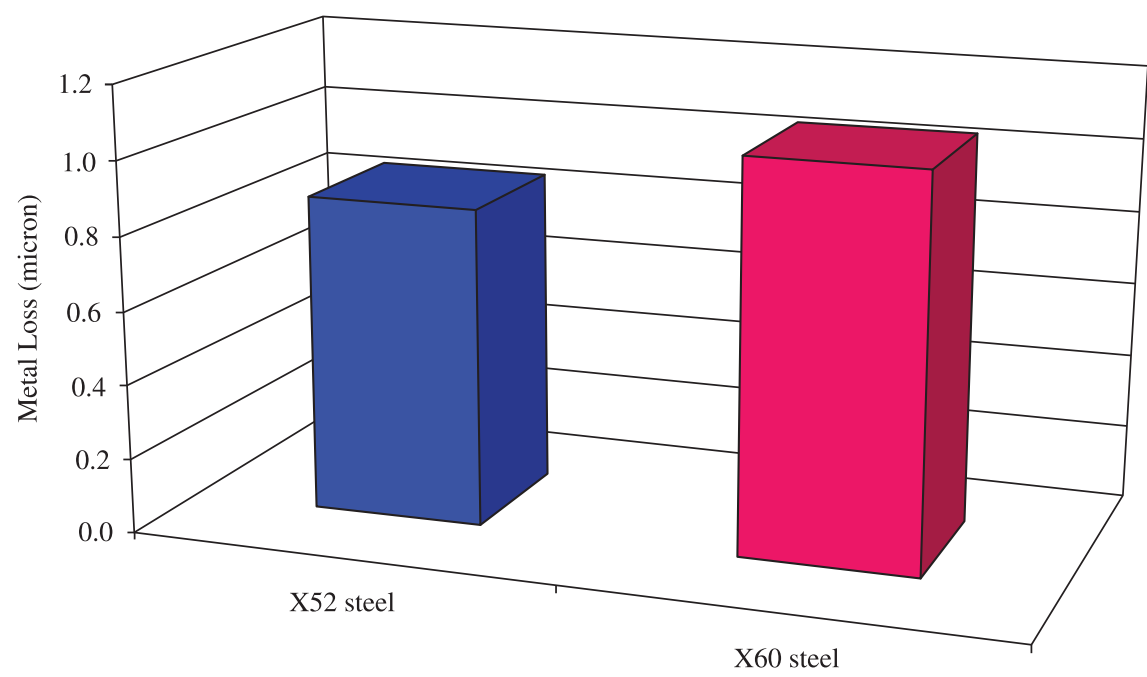

Figure 5. The total amount of metal lost for X52 and X60 steels. 


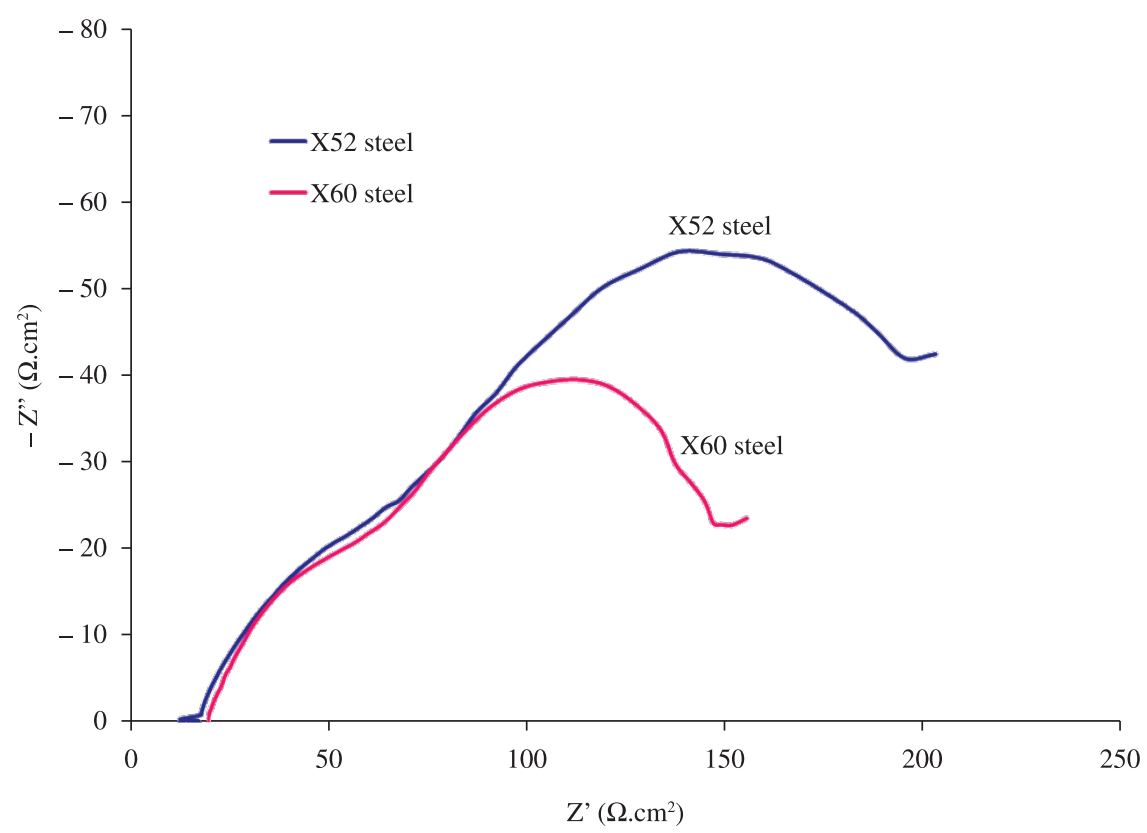

Figure 6. The Nyquist diagrams of X52 and X60 steels.
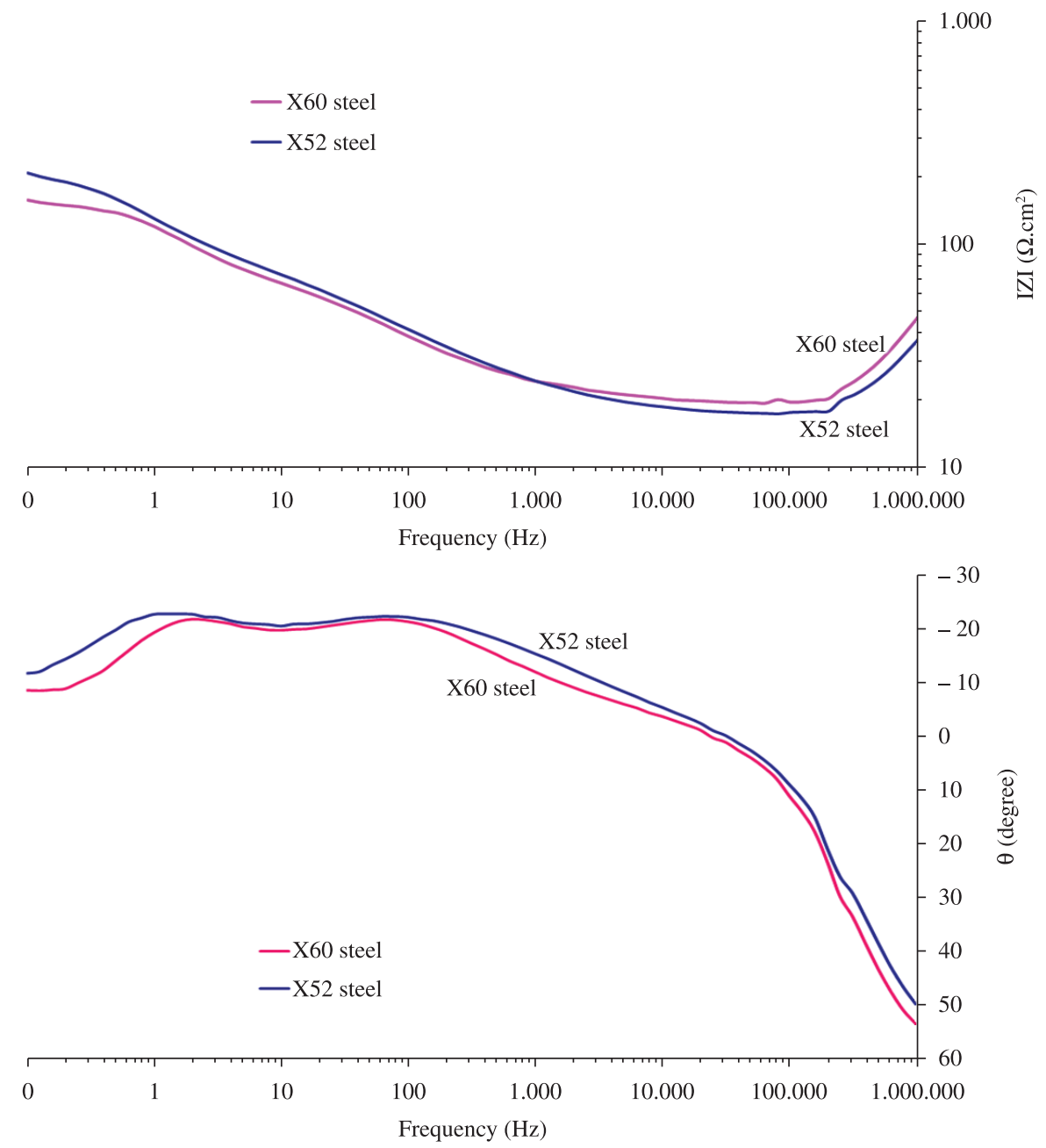

Figure 7. The Bode diagrams of X52 and X60 steels. 


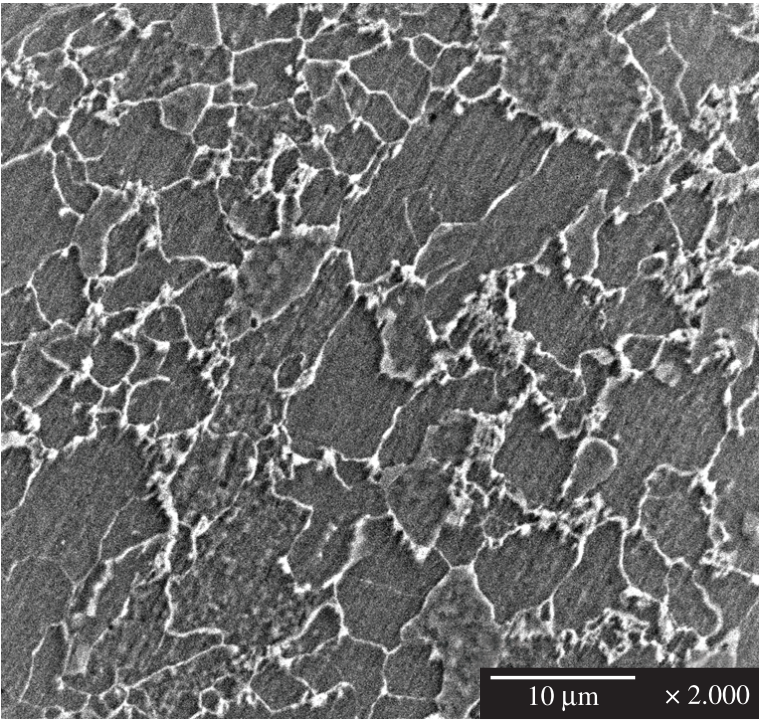

(a)

Figure 8. The microstructure of a) X52 steel and b) X60 steel.

two working electrodes. They varied between 0.5 and $0.7 \mathrm{~mm} . \mathrm{y}^{-1}$. Moreover, it seems that, passivation happened within the first hour of the experiment for both steels substrates, which was confirmed by the rapid increase in the corrosion potential.

\subsection{Microstructure}

The two steels (X60 and X52) have similar microstructure, as shown in Figure 8 (SEM imagery). Both images show pearlite (dark) with ferrite (bright) at the grain boundaries, and with relatively higher ferrite content for $\mathrm{X} 52$ steel. This is in agreement with similar microstructure obtained by others ${ }^{37-39}$. The microstructure has an effect on corrosion through the galvanic effect between pearlite and ferrite, which enhances the corrosion of the ferrite ${ }^{39}$ because the cementite which is contained in the pearlite is electrochemically more stable than ferrite ${ }^{40}$. The higher corrosion rate of $\mathrm{X} 60$ steel can be related to the relatively lower content of ferrite than that of X52 steel.

The samples were prepared by polishing to 3 microns, and etching using $2 \%$ Nital solution ( $2 \%$ nitric acid $+98 \%$ ethanol).

\section{References}

1. Dawe RA, editor. Modern Petroleum Technology. 6th ed. The Institute of Petroleum, John Wiley \& Sons LTD; 2000. vol. 1, p. 319.

2. Li H, Huang J, Sormaz D and Nesic S. A Free Open Source Mechanistic Model for Prediction of Mild Steel Corrosion. In: Proceedings of the 17th International Corrosion Congress; 2008; Las Vegas. Las Vegas; 2008. Paper no. 2659.

3. Nesic S, Li H, Huang J and Sormaz D. An Open Source Mechanistic Model for $\mathrm{CO}_{2} / \mathrm{H}_{2} \mathrm{~S}$ Corrosion of Carbon Steel. In: Proceedings of the NACE International Corrosion Conference \& Expo; 2009; Atlanta. Atlanta: NACE International; 2009. Paper no. 09572

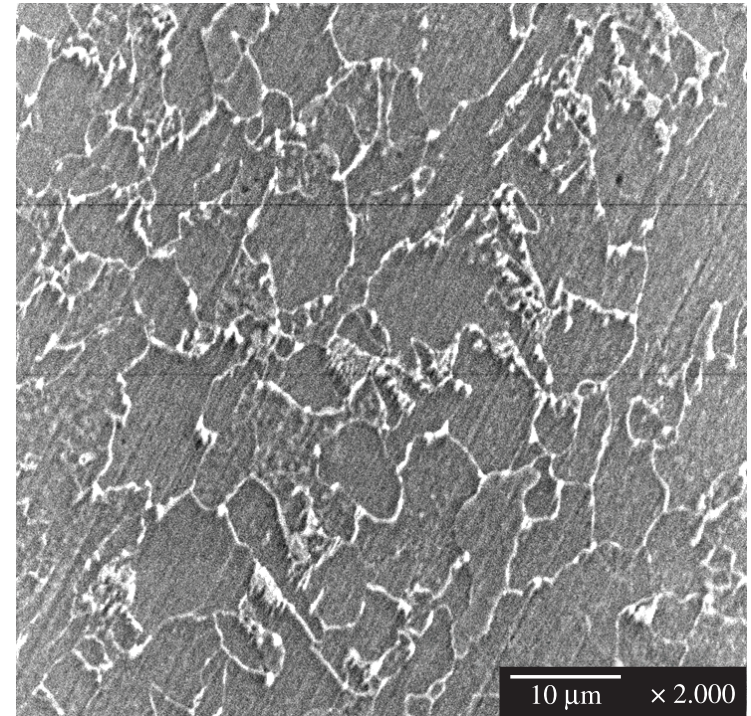

(b)

\section{Conclusion}

Two principal conclusions may be drawn:

Polished HSLA steel coupons (X60 and X52) showed corrosion rates (typically) of 1.0 to $1.8 \mathrm{~mm} . \mathrm{y}^{-1}$ while exposed to $\mathrm{CO}_{2}$ containing saltwater, although the rate was reduced after one hour. This rate reduction is attributed to formation of a protective film.

Steel of the type X52 showed superior resistance to corrosion as compared X60 steel, under conditions of $\mathrm{pH} 4.4$ and $50{ }^{\circ} \mathrm{C}$.

\section{Acknowledgements}

The author would like to acknowledge the Center of Engineering Research-Research Institute and Center of Research Excellence in Corrosion (CoRE-C) at King Fahd University of Petroleum \& Minerals (KFUPM) for supporting this research. The author would like to acknowledge Dr. Blair Bremberg at Research Institute-KFUPM for editing the manuscript.

4. Delahay P. Implications of the Kinetics of Ionic Dissociation with Regard to Some Electrochemical Processes-Application to Polarography. Journal of the American Chemical Society. 1952; 74(14):3497-500. http://dx.doi.org/10.1021/ ja01134a013

5. Nesic S, Postlethwaite J and Olsen S. An Electrochemical Model for Prediction of $\mathrm{CO}_{2}$ Corrosion. In: Proceedings of the Corrosion/95; 1995; Orlando. Houston: NACE International; 1995. Paper no. 131. PMCid:231997.

6. Han J, Young D and Nesic S. Characterization of the Passive Film on Mild Steel in $\mathrm{CO}_{2}$ Environments. Proceedings of the 17th International Corrosion Congress; 2008; Las Vegas. Las Vegas; 2008. Paper no. 2511. 
7. De Waard C and Milliams DE. Carbonic Acid Corrosion of Steel. Corrosion. 1975; 31:177-188.

8. Van Hunnik EWJ, Pots BFM and Hendriksen ELJA. The Formation of Protective $\mathrm{FeCO}_{3}$ Corrosion Product Layers in $\mathrm{CO}_{2}$ Corrosion. In: Proceedings of the Corrosion/96; 1996; Denver. Houston: NACE International; 1996. Paper no. 6.

9. Choi Y and Nesic S. Corrosion Behavior of Carbon Steel in Super Critical $\mathrm{CO}_{2}$-Water Environments. In: Proceedings of the Corrosion/09; 2009; Atlanta. Houston: NACE International; 2009. Paper no. 256.

10. Choi Y-S, Nesic S, Duan D and Jiang S. Mechanistic Modeling of Carbon Steel Corrosion in a MDEA-Based $\mathrm{CO}_{2}$ Capture Process. In: Proceedings of the NACE International Corrosion Conference \& Expo; 2012; Salt Lake City. Salt Lake City; 2012. Paper no. C2012-0001321.

11. Nyborg R. Overview of $\mathrm{CO}_{2}$ Corrosion Models for Wells and Pipelines. In: Proceedings of the NACE International Corrosion Conference \& Expo; 2003; Houston. Houston; 2003. Paper no. 02233.

12. Nesic S, Postlethwaite J and Olsen S. An Electrochemical Model for Prediction of Corrosion of Mild Steel in Aqueous Carbon Dioxide Solutions. Corrosion Science. 1996; 52(4):280-294. http://dx.doi.org/10.5006/1.3293640

13. Nesic S. Key Issues Related to Modelling of Internal Corrosion of Oil and Gas Pipelines - A Review. Corrosion Science. 2007; 49(12):4308-4338. http://dx.doi.org/10.1016/j. corsci.2007.06.006

14. Kermani MSL. $\mathrm{CO}_{2}$ corrosion control in the oil and gas production design considerations. European Federation of Corrosion; 1997.

15. Nelson P and Still JR. Metallurgical Failures on Offshore Oil Production Installations. Metals \& Materials. 1988; 559-64.

16. Almansour MA. Sulfide Stress Cracking Resistance of Api-X100 high strength low alloy steel in $\mathrm{H}_{2} \mathrm{~S}$ environments. [Thesis]. Vancouver: The University of British Columbia; 2007.

17. Makrides $\mathrm{AC}$ and Hackerman N. Dissolution of Metals in Aqueous Acid Solutions. Journal of The Electrochemical Society. 1958; 105:156-162. http://dx.doi. org/10.1149/1.2428782

18. Silverman DC and Zerr ME. Application of the Rotating Cylinder Electrode - E-Brite 26-1/Concentrated Sulfuric Acid. Corrosion. 1986; 42:633-640. http://dx.doi. org/10.5006/1.3583034

19. Tian BR and Cheng YF. Electrochemical Corrosion Behavior of X-65 Steel in the Simulated Oil Sand Slurry. I: Effects of Hydrodynamic Condition. Corrosion Science. 2008; 50(3):773-9. http://dx.doi.org/10.1016/j. corsci.2007.11.008

20. Zhang GA and Cheng YF. Electrochemical Corrosion of X65 Pipe Steel in Oil/Water Emulsion. Corrosion Science. 2009; 51:901-907. http://dx.doi.org/10.1016/j. corsci.2009.01.020

21. Becerra HQ, Retamoso $C$ and Macdonald DD. The Corrosion of Carbon Steel in Oil-in-Water Emulsions Under Controlled Hydrodynamic Conditions. Corrosion Science. 2000; 42(3):561-575. http://dx.doi.org/10.1016/ S0010-938X(99)00068-2

22. Meyer U, Brosnan CC, Bremhorst K, Tomlins R and Atrens A. New Impinging Jet Test Rig Used to Identify the Important Parameters in Service Erosion-Corrosion in Bayer Liquor and to Study the Damage Morphology. Wear. 1994; 176:163-171. http://dx.doi.org/10.1016/0043-1648(94)90144-9
23. Tang X, Xu LY and Cheng FY. A Fundamental Understanding of Erosion Corrosion of Hydrotransport Pipes in Oil Sands Slurry. In: Proceedings of the 2nd Biennial International Pipeline Conference - IPC; 2008; Calgary. International Petroleum Technology Institute and the Pipeline Division; 2008. p. 275-280. http://dx.doi.org/10.1115/IPC2008-64144

24. Tang X, Xu LY and Cheng YF. Electrochemical Corrosion Behavior of X-65 Steel in the Simulated Oil Sand Slurry II: Synergism of Erosion and Corrosion. Corrosion Science. 2008; 50(5):1469-74. http://dx.doi.org/10.1016/j. corsci.2008.01.019

25. Papavinasam S, Doiron A, Panneerselvam $T$ and Revie RW. Effect of hydrocarbons on the internal corrosion of oil and gas pipelines. Corrosion. 2007; 63(7):704-12. http://dx.doi. org/10.5006/1.3278419

26. Castle JE and Masterson HG. The Role of Diffusion in the Oxidation of Mild Steel in High-Temperature Aqueous Solutions. Corrosion Science. 1966; 6:93-104. http://dx.doi. org/10.1016/S0010-938X(66)80001-X

27. Bignold GJ. Cyclic Voltammetry at the Iron Electrode in High-Temperature Aqueous Sodium Hydroxide Solutions. Corrosion Science. 1972; 12:145-154. http://dx.doi. org/10.1016/S0010-938X(72)90874-8

28. Bignold GJ, Garnsey R and Mann GMW. High-Temperature Aqueous Corrosion of Iron, Development of Theories of Equilibrium Solution Phase Transport Through a Porous Oxide. Corrosion Science. 1972; 12:325-332. http://dx.doi. org/10.1016/S0010-938X(72)90962-6

29. Rihan RO and Nesic S. Erosion-Corrosion of Mild Steel in Hot Caustic, Part I - Pure $\mathrm{NaOH}$ Solution. Corrosion Science. 2006; 48:2633-2659. http://dx.doi.org/10.1016/j. corsci.2005.09.018

30. Rihan RO and Nesic S. Erosion-corrosion of Mild Steel in Hot Caustic. Part II - The Effect of Acid Cleaning. Corrosion Science. 2006; 48:2660-2675. http://dx.doi.org/10.1016/j. corsci.2005.09.019

31. Rihan RO. Erosion-Corrosion of Mild Steel in Caustic and Inhibited Acid Solution. [Thesis]. Brisbane: University of Queensland; 2001.

32. Villarreal J, Laverde D and Fuentes C. Carbon-Steel Corrosion in Multiphase Slug Flow and $\mathrm{CO}_{2}$. Corrosion Science. 2006; 48:2363-2379. http://dx.doi.org/10.1016/j. corsci.2005.09.003

33. Kvarekval J. Flow Loop Studies of the Relationship Between Limiting Currents and $\mathrm{CO}_{2} / \mathrm{H}_{2} \mathrm{~S}$ Corrosion of Carbon Steel. In: Proceedings of the Corrosion/98; 1998; San Diego. Houston: NACE International; 1998. Paper no. 44.

34. Fu SL and Strickland JB. Corrosion Study in Dynamic High Velocity Flow Application Based on New Flow Loop Data. In: Proceedings of the Corrosion/93; 1993; New Orleans. Houston: NACE International; 1993. Paper no. 117.

35. Kang C, Jepson WP and Wang H. Flow Regime Transitions in Large Diameter Inclined Multiphase Pipelines. In: Proceedings of the Corrosion/02; 2002; Denver. Houston: NACE International. 2002. Paper no. 02243.

36. Tang X, Li C, Ayello F, Cai J, Nesic S, Ivan C, Cruz T and Al-Khamis JN. Effect of Oil Type on Phase Wetting Transition and Corrosion in Oil-Water Flow. In: Proceedings of the Corrosion/07; 2007; Nashville. Houston: NACE International; 2007. Paper no. 07170.

37. Dong R, Sun I, Liu Z, Wang X and Liu Q. Microstructures and Properties of X60 Grade Pipeline Strip Steel in CSP Plant. Journal of Iron and Steel Research International. 2008; 15(2):71-75. http://dx.doi.org/10.1016/S1006-706X(08)60035-7 
38. Clover D, Kinsella B, Pejcic B and De Marco R. The Influence of Microstructure on the Corrosion Rate of Various Carbon Steels. Journal of Applied Electrochemistry. 2005; 35:139-149. http://dx.doi.org/10.1007/s10800-004-6207-7

39. Du CW, Li XG, Liang P, Liu ZY, Jia GF and Cheng YF. Effects of Microstructure on Corrosion of X70 Pipe Steel in an Alkaline Soil. Journal of Materials Engineering and
Performance. 2009; 18(2):216-220. http://dx.doi.org/10.1007/ s11665-008-9280-y

40. Gulbrandsen E, Nyborg R, Loland T and Nisancioglu K. Effects of Steel Microstructure and Composition on Inhibition of $\mathrm{CO}_{2}$ Corrosion. In: Proceedings of the Corrosion/2000; 2000; Orlando. Houston: NACE International; 2000. Paper no. 00023. 